\title{
ECONOMIC DECline AND Extreme-Right Electoral Threat: How District-Level Factors shape the Legislative Debate ON IMMIGRATION
}

\author{
Eitan Tzelgov* \\ Petrus Sundin Olander ${ }^{\dagger}$
}

August 7, 2018

\begin{abstract}
This research examines the degree to which legislators respond to their districts by analyzing immigration-related legislative speeches from the Swedish parliament (2005-2016). Using a text-scaling method, we find that the immigration discourse fluctuates between 'socio-economic responsibility' and 'cultural difference' poles. We argue that socioeconomic declines and extreme-right party success serve as an indication to MPs that there is demand for 'cultural difference' rhetoric on immigration. Our statistical analyses support the argument and demonstrate that district-level economic declines can lead to an increase in the salience of cultural framing of migrants, especially in districts with a higher share of foreign residents. We also find that district-level extreme-right electoral success has a significant influence on legislative immigration discourse. Overall, the results have implications for studies of legislative texts, dyadic representation, and the impact of the populist right on legislative politics in Europe.
\end{abstract}

\footnotetext{
${ }^{*}$ Lecturer in Politics, University of East Anglia, UK

${ }^{\dagger}$ PhD Student, Department of Political Science, University of Gothenburg, Sweden
} 


\section{INTRODUCTION}

Politicians don't often cry in public. And yet, in November 2015, the Swedish deputy Prime Minister, heading a pro-immigration governing coalition, broke into tears as she was describing new, restrictive immigration policies. She then rationalized this policy U-turn by claiming it was a necessary step to respond to the difficulties members of her party were facing at the local level. To us, this memorable press conference demonstrates the degree to which legislators are always required to respond to the information reported from their constituencies. This responsiveness is especially important during periods of systemic shocks such as the immigration crisis faced by European countries over the last few years. These periods provide a favourable political opportunity structure for political entrepreneurs (Arzheimer and Carter, 2006, Kitschelt, 1986), who try to use crises to reshape the political agenda to their advantage. In these cases, mainstream politicians use available information regarding social, economic and electoral conditions to make costly decisions as to which issues to address and what positions to take on these issues (Borghetto and Russo, 2018; Klüver and Sagarzazu, 2015).

But what factors affect the ability of mainstream politicians to respond to voters' preferences? And what information do they rely on to learn about those preferences? Previous studies have pointed to aspects such as past electoral results, economic conditions, government participation, mainstream/niche status, party size, family and ideological positioning relative to newcomers and promoters of new issues (Adams et al., 2004, Adams and Somer-Topcu, 2009; Greene, 2016; Green-Pedersen, 2007). While there is evidence of parties responding to voter preferences on the national party level, we know less about the responsiveness that exists at the district-level.

Most studies approach the topic of responsiveness by analyzing election manifestos or party press releases. This modeling approach is lacking on two fronts. First, by focusing on election campaigns, the research neglects the dynamic during the life of the legislature. Second, analysis of party documents does not take into account divergences across legislators. However, since legislators take into account district-level factors as they decide whether and how to address an issue or a political newcomer, we believe it is essential to incorporate these factors into the analysis.

The approach taken here is therefore to analyse the MP-district nexus. We focus on responsiveness in the context of immigration politics. Beyond its 
current impact on global and national politics, we believe immigration is of utter importance to broad theoretical debates in the study of party strategy and responsiveness. Firstly, the issue is challenging for political elites, since it does not map well onto established ideological dimensions, and may lead to party factionalism, splits, and party-system realignments (Benoit and Laver, 2007, Bornschier, 2010b; Kriesi et al., 2008; Green-Pedersen and Krogstrup, 2008). Secondly, the magnitude of migration waves provides an improved political opportunity structure for political entrepreneurs Arzheimer and Carter, 2006; Kitschelt, 1986). Thirdly, as Van Der Brug and Van Spanje (2009) argue, there is a demand for parties expressing cultural (immigrationrelated) positions, coupled with economic left-wing positions (Mudde, 2007), and therefore the immigration issue can have a profound impact on the future configuration of party competition.

The concept of demand for culturally based positions on immigration is central to our thesis. Given that there is cross-district variation in this demand, we conceptualize responsiveness as a process by which electorally oriented MPs use socio-economic, demographic, and electoral district information as cues about the level of this demand. If the district demand is high, MPs will respond by focusing more on the cultural aspects of immigration, at the expense of discussing the economic aspects of it.

We derive this approach from two strands of the literature on the structure of party competition in Europe. First, country-specific and comparative studies on political dimensionality and competition report a shift from a unidimensional left-right structure towards a multi-dimensional/issue-oriented configuration, in which, over time, the overall salience of social issues is increasing (Green-Pedersen, 2007; König et al., 2017; Prosser, 2016; van Kersbergen and Krouwel, 2008). Second, literature dealing with immigration positions finds that, while mainstream parties' positions on immigration can be mainly predicted by their position on the economic left-right scale, citizens' positions on the issue are actually more related to a cultural dimension (Hooghe and Marks, 2018; Van Der Brug and Van Spanje, 2009). Thus, under certain conditions, MPs are expected to respond to the demand by addressing the cultural aspects of immigration.

But what factors predict these type of responsiveness, by which legislators shift from an emphasis on the economic aspects of immigration to its cultural aspects? Economic and social declines have been shown to lead to increased support for right-wing parties (Betz, 1993; Hagelund, 2003; Hobolt and Tilley, 2016), as well as to negative attitudes towards globalization, the 
EU, and immigration (Clarke et al., 2017; Haidt, 2016, Burscher et al., 2015; Dinas and van Spanje, 2011). Therefore, we expect MPs representing districts that have experienced such declines to shift toward culturally oriented rhetoric. However, we believe that the relationship between socio-economic deterioration and shifts towards this type of discourse is conditional on two important factors. First, much like Hobolt and Vries (2015) and Spanje (2010), who study how government status affects responsiveness, we expect opposition MPs to be more responsive. Second, we expect a stronger relationship between socio-economic deterioration at the district level and MPs' responsiveness in districts that are characterized by a higher share of foreign-born residents (see, for example, Golder, 2003). Third, we believe the electoral threats posed by extreme right parties (ERPs) matters. Studies of party positions and issue attention (Adams and Somer-Topcu, 2009 Meguid, 2005; Spoon et al. 2013) have found that electoral threat is likely to affect both party positioning overall, as well as in the specific case of ERPs and immigration (Abou-Chadi, 2016; Bale, 2003, Dahlstrom and Sundell, 2012; Spanje, 2010). Thus, we expect district-level success of ERPs to predict responsiveness, that is, a shift of mainstream MPs from the district towards a cultural immigration discourse.

To test these hypotheses, we derive estimates of MPs' position on immigration, using Slapin and Proksch's (2008) wordfish model. We scale 5199 immigration legislative speeches given in the Swedish Riksdag during the 2005-2016 period. We find that speeches can best be ordered on a scale ranging between two extremes, the first being a 'socio-economic responsibility' pole, and the second a 'cultural difference' pole. This scale echoes frames identified in other European countries (Hagelund, 2003; van Kersbergen and Krouwel, 2008; Van-Heerden et al., 2014). We then leverage a battery of social, economic and electoral variables, as well as institutional and MP-level variables to predict MPs' immigration positions and rhetorical responsiveness.

Our statistical analyses provide a number of important results. First, we find robust evidence that changes in the economy have an impact on legislative rhetoric. Specifically, economic declines predict responsiveness, that is, shifts towards a cultural difference discourse. When we explore the factors that condition this type of responsiveness, we find mixed results. Contrary to our expectation, we find only weak evidence regarding the difference between government and opposition MPs. However, when it comes to the ethnic composition of the district, we find that the responsiveness of MPs is stronger as the share of foreign-born residents in the district increases. 
Finally, we find that district-level ERP success also predicts a shift towards cultural difference discourse.

The results have a number of important implications. First, they provide additional evidence of the growing importance of issue politics in Europe, and especially of the increased salience of cultural politics (Green-Pedersen, 2007; König et al., 2017; van Kersbergen and Krouwel, 2008). We believe that our empirical findings, which echo the theoretical literature on the demand for culturally oriented politics among the working class (Hooghe and Marks, 2018; Van Der Brug and Van Spanje, 2009), are helpful in understanding some of the new political discourses and alliances in European politics. Second, the fact that responsiveness among legislators is conditional on the ethnic composition of the district may have useful policy implications. Finally, the fact that ERPs' electoral success affects political language is especially important. Mudde (2013) has argued that the influence of ERPs on the issue of immigration is limited, but here we show that ERPs are influential, since mainstream MPs use their success to gauge the demand for culturally oriented politics. More broadly, ERPs are changing the way in which mainstream politicians discuss immigration. Indeed, this research provides evidence that even when ERPs do not win the electoral race, their electoral threat has an impact on the political discourse in Europe.

\section{District-level Responsiveness on Immigration: How THE LOCAL AND INSTITUTIONAL INTERACT}

Why do legislators speak in parliament? We follow the literature arguing that politicians use their time on the floor for credit claiming, or as a means of highlighting MPs' positions to voters and other political actors (Herzog and Benoit, 2015; Maltzman and Sigelman, 1996; Martin and Vanberg, 2007; Mayhew, 1974; Proksch and Slapin, 2010). Among other things, MPs use their speeches to signal their constituencies that their position is responsive to the needs of the district. This signaling behavior involves a process by which the MP observes the relevant conditions in her district. Based on this information, she decides whether to address an issue, and in what way.

This type of dyadic representation has been studied most thoroughly in the candidate-centered system of the United States (Ansolabehere et al., 2001, Krimmel et al., 2016), and recently in the UK (Hanretty et al., 2016). But in strong party systems such as the Swedish, some research suggests that 
district-level congruence is manifested via MPs' parliamentary questions, speeches, and bill cosponsorship (Baumann et al., 2015: Fernandes et al. 2017). Further, the Swedish open-list PR system should encourage some level of personal vote-seeking (Carey and Shugart, 1995) and dyadic representation. Studies of the Swedish system support this expectation by highlighting the pressure local party activists exert on MPs (Butler et al., 2016), and the fact that MPs report district-level representation to be important (Gilljam and Brothen, 1994).

There is vast literature demonstrating that parties use information on voting intentions and voters' preferences to adjust their positions (Adams et al. 2008, 2004 Somer-Topcu, 2009). Another strand of the literature shows that parties modify their attention based on changes in voters' issues salience (Borghetto and Russo, 2018, Klüver and Sagarzazu, 2015; Klüver and Spoon, 2016), and that their ability to adjust is conditional on institutional variables such as government status (Heck, 2016; Spanje, 2010). Another set of works address electoral challenges, and parties' response to shifts in the positions of rival parties or niche party entry (Abou-Chadi, 2016; Meguid, 2005, Adams and Somer-Topcu, 2009; Spoon et al., 2013).

Our research builds on this literature but goes beyond the party as a unified actor approach. Specifically, we analyze the degree to which MPs, rather than parties, respond to district constituencies (Hanretty et al., 2016, Ansolabehere et al., 2001; Krimmel et al., 2016). Similar to Herzog and Benoit (2015), who analyse legislators' rhetoric and correspondence with district conditions, we test whether district-level socio-economic changes correlate with MPs' language. Our first expectation is that MPs elected in districts where there has been socio-economic deterioration will emphasize the cultural aspects of immigration in their speeches, rather than its economic aspects.

The first reason for this expectation has to do with changes in the structure of party competition in Europe. An important line of research has identified an emerging, cross-cutting, cultural conflict. This conflict is structured around European integration, nationalism, identity, and anti-immigration (Bornschier, 2010a; Hoeglinger, 2016; Hooghe et al., 2002, Hooghe and Marks, 2009). Moreover, this conflict pits the economic losers of processes of integration and globalization against the winners (Kriesi et al., 2006). Recently, Hooghe and Marks (2018) go as far as arguing that the migration crisis has led to a new, transnational cleavage, in which losers of globalisation processes find refuge in increased nationalism. In addition, research points to a 
relationship between socio-economic hardships and opposition to globalization, European integration, and migration, perceived as a threat to national culture and tradition (Burns and Gimpel, 2000; Clarke et al., 2017, Haidt, 2016).

Issue competition (Carmines and Stimson, 1990) has also become increasingly relevant in European politics, both overall and in the case of immigration (Green-Pedersen, 2007; Green-Pedersen and Krogstrup, 2008). Indeed, in the Netherlands, de Vries et al. (2013) find that attitudes toward immigration are more predictive of voters' left-right placement than their attitudes towards economic distribution. In addition to the increasing importance of non-economic issues, parties' positions are more congruent with those of citizens on socio-economic issues than on cultural issues such as immigration (Dalton, 2015; Van Der Brug and Van Spanje, 2009). As Dalton and McAllister (2014) note, parties' positions are 'sticky' and thus it may take time until they respond to voters' preferences.

As cultural politics becomes more salient, and the lack of congruence between parties and voters becomes apparent, mainstream parties face a dilemma. On the one hand, they may benefit from an electoral landscape characterized by economic issues, which they own, rather than increase the salience of other issues (Norris, 2005; Meguid, 2005). On the other hand, parties may want to take advantage of the opportunity if there is sufficient demand for culturally oriented politics (Schumacher and Kersbergen, 2014). Districtlevel variation in socio-economic conditions may help parties to solve this dilemma. Specifically, district-level economic deterioration signals to politicians that there is demand for culturally oriented discourse. This leads to the first hypothesis:

Hypothesis 1: (The responsiveness hypothesis): District-level socio-economic deterioration predicts responsiveness, that is, a shift toward culturally oriented rhetoric.

However, MPs' response to this demand is conditional on a number of factors. First, governing parties can only devote limited attention to new issues, because they are constrained by political events, policy-making, and maintaining a coherent policy agenda. Opposition parties are less constrained and are therefore expected to shift their attention to external issues (Klüver and Spoon, 2016, Williams and Spoon, 2015). Beyond government constraint, the opposition, who are the losers in the current state of affairs, have an incentive to reshape the structure of the debate by changing the issues on the agenda (Carmines and Stimson, 1990; Riker, 1986, Tzelgov, 2012). Van- 
Spanje (2010) and Hobolt and Vries (2015) have used similar reasoning to explain why opposition parties are more likely than governing ones to take on anti-immigration positions in response to ERPs success. This leads to the following expectation:

Hypothesis 1a: (The opposition hypothesis): The relationship between districtlevel socio-economic deterioration and responsiveness is conditional on governmentopposition status. Specifically, the marginal effect of socio-economic deterioration is stronger for opposition MPs than for government MPs.

While we expect socio-economic deterioration to increase the demand for cultural rhetoric on immigration, we also hypothesize that the relationship between this deterioration and rhetoric is conditional on the demographic composition of the district. This expectation mirrors studies focusing on 'locals' seeing newcomers as competitors over scarce resources, in aspects such as labour, housing, and welfare benefits (Fennema, 2005). For example, a comparative study by Golder (2003) has found that unemployment moderates the effect of immigration on ERP support, but in the Swedish context, Rydgren and Ruth (2011) and Rydgren and Ruth (2013) find mixed results. Following this literature, we specify the next hypothesis:

Hypothesis 1b: (The demography hypothesis) : The relationship between district-level socio-economic deterioration and responsiveness is conditional on the ethnic composition of the district. Specifically, the marginal effect of socio-economic deterioration is stronger in districts in which the share of foreign-born residents is increasing.

\section{EleCtORAL THREAT AND ResPONSIVENESS}

The increasing rates of migration into Sweden have been accompanied by a steady increase in the electoral appeal of the Swedish ERP, the Sweden Democrats. The Swedish ERP poses a threat to both right and left-wing parties (Odmalm, 2011; Oskarson and Demker, 2015). But how would an electoral threat affect legislative rhetoric? The spatial theory of party competition connects electoral threats to spatial movements (Enelow and Hinich, 1984). Parties have been found to modify their positions in response to past election results (Somer-Topcu, 2009), changes in public opinion (Adams et al. 2004), and due to an electoral threat by niche parties (Meguid, 2005). In addition, studies of 'contagion effects' have found that ERPs' success leads mainstream politicians to adopt restrictive immigration positions and 
welfare chauvinist frames (Dahlstrom and Sundell, 2012, Schumacher and Kersbergen, 2014: Van-Spanje, 2010). Viewed through the theoretical framework of responsiveness, we conceive mainstream parties as using past ERP electoral success to gauge the demand for cultural rhetoric on immigration, which is a dominant feature of ERPs (Hagelund, 2003; van Kersbergen and Krouwel, 2008, Van-Heerden et al., 2014).

Hypothesis 2: Sweden Democrats district-level electoral success predicts mainstream MPs responsiveness.

\section{Legislative SpeEch DATA}

\section{Data Preparation}

To prepare the rhetorical data, we have downloaded all of the floor debates during the 2005-2016 period from the Riksdag's website. We then used python scripts to produce a dictionary containing the most frequent 7,000 Swedish stems 11 Following previous work analysing legislative speeches (Lauderdale and Herzog, 2016, Lucas et al., 2015; Proksch and Slapin, 2009), we removed stop words, numbers and legislator names ${ }^{2}$

We have identified immigration debates using an iterative process. Initially, we constructed a dictionary of immigration-related words. We then used the dictionary to automatically search through the headings of the 20,814 debates. Once a round of automated search ended, we examined all the headings and read a sample of the debates identified as relevant, and subsequently dropped cases that were erroneously classified. Second, after reading the headings of debates that were left out of the immigration corpus, we have used words from the headings of these debates to refine the dictionary and rerun the automated search, until we found no debates that were left out or needed to be omitted 3

\footnotetext{
${ }^{1}$ Stemming was done using python's NLTK snowball stemmer, and by the SnowballC $\mathrm{R}$ package.

${ }^{2}$ Substantive results are not sensitive to the removal of these features.

${ }^{3}$ See the supporting material for a detailed discussion.
} 


\section{MODEL INTERPRETATION}

We have used Slapin and Proksch's (2008) algorithm to estimate MPs expressed positions on immigration. 4 To calibrate the estimates across parties and time, we omitted terms that have not been used both pre and post the 2015 immigration crisis. We also limited our vocabulary to words that MPs from all parties have used. As a result, our document-term matrix includes 5199 speeches and 588 unique stems ${ }^{5}$

We are interested in two parameters estimated by the model. The first is the (word-specific) $\beta$ parameter, which reports how informative a word is in discriminating across the positions of speeches. Second, we are interested in the (speech-specific) $\omega$ parameter, which is an estimate of the position of the speech in the latent space. Table 1 presents the scaling model's output in terms of discriminatory words (large absolute values of the $\beta$ parameter).

Most words in the left column refer to social and economic issues facing immigrants, as well as to the responsibility of the Swedish authorities both at the national and municipal level. We also note that a number of words point to the hardships experienced by immigrants. In the right column, most words are characteristic of cultural differences between immigrants and locals, and to inter-group conflict. Overall, these two extremes echo frames of reference identified in the literature on the immigration discourse in Western Europe (Hagelund, 2003, Rydgren, 2008; van Kersbergen and Krouwel, 2008; Minkenberg, 2001; Van-Heerden et al., 2014).

Based on the words identified as discriminatory by the statistical model and our reading of hundreds of speeches, we conclude that one pole of the immigration rhetoric highlights 'socio-economic responsibility' towards immigrants. As an example, consider the following speech, made on April 2015 by Yilmaz Kerimo, a Social Democrat MP: " Of course, there is no need to review the entire refugee reception and EBO [a law allowing refugees to settle where they wish in Sweden]... On the other hand, the regulations can be revised with regards to how we can encourage other municipalities to receive refugees so that the reception process will be characterized by solidarity. We can also reduce the prejudices that exist for better and easier integration

\footnotetext{
${ }^{4}$ For other implementations using legislative speeches, see Baumann et al. (2015); Proksch and Slapin (2010); Slapin and Proksch (2008).

${ }^{5}$ The median length is 61 words, and the mean 89 . The shortest speech has 20 words and the longest 930. The standard deviation is 81.6. We estimated the model using these speeches as (unaggregated) input, using the austin package in $\mathrm{R}$ 3.3.2.
} 
Table 1: 25 Characteristic words: Socio-Economic ResponsibiLity and Cultural Difference Poles

\begin{tabular}{ll}
\hline Low $\beta$ & HIGH $\beta$ \\
\hline \hline municipality & hate crime \\
unaccompanied youth (migrants) & extremism \\
woman & Muslim \\
child & terrorism \\
against & racism \\
work/job & scrutiny \\
refugee receptions & religion \\
reception & Iraqi \\
responsibility & pupil \\
believe & democratic \\
refugee & ethnic \\
labour market & damage \\
good & democracy \\
accommodation & free \\
more & fight \\
here & national \\
employment & crime \\
responsible & discourage \\
work & culture \\
responsibility & threat \\
education & Iraq \\
establishment & conclusion \\
move/flee & probable \\
order & commission \\
situation & stop \\
\hline
\end{tabular}

Note: Discriminatory words obtained from Slapin and Proksch s (2008) scaling model.

where there are jobs and housing in other municipalities." Another speech, made by Nyamki Sabuni on April 2010 exemplifies the socio-economic responsibility pole: "I think that all those [municipalities] who receive refugees need extra resources if these children are able to manage their schooling ... I do not want a compensation scheme for only some municipalities ... $[\mathrm{W}]$ hat I mean is the future should be considered when we discuss solidarity in reception."

The other pole of the immigration debate emphasizes 'cultural difference' as 
well as friction between immigrants and other communities in Sweden. For example, on May 2011, Björn Söder, of the Sweden Democrats, said: "It is often said that intolerance has increased among school students in Sweden. For example, students are asked whether they think immigration is good for the Swedish economy. If they answer 'no' to this question, it contributes to a higher intolerance score in the report. Does the Prime Minister see a risk when work against xenophobia, such as this survey, paints any critique of migration policies as racism? And why is there no mention of the extensive "hostility towards Swedes" in the investigative directive?" Similarly, Johan Linander (Centre party), said on January 2011: "Just as Muslims are in need to combat violent Islamism, the Sweden Democrats have a responsibility to do what they can to counter high-extremist or Islamophobic forces who listen to their message about Muslims.' 6

We emphasize that these two poles do not correspond to pro- and antiimmigrant attitudes.$^{7}$ but are indicative of the rhetorical frames chosen by MPs as they address the immigration issue. Thus, it is entirely possible for an MP to hold pro-immigration views and yet discuss cultural difference issues. Conversely, there are instances in which anti-immigrant MPs discuss the degree to which Sweden is responsible for migrants.

\section{VALIDATION}

We now turn to a quantitative examination of characteristic speeches, that is, those that have high absolute values of the $\omega$ parameter. First, in Figure 1. we present the distribution of median MP positions by party. Two things emerge from the figure. First, MPs across all parties - with the exception of the Sweden Democrats - express positions across the entire range of the scale 8 This echoes Widfeldt's (2015) argument, that one would be hardpressed to find differences between parties on immigration. Second, the median position for the Sweden Democrats (sd in the figure) is the most cultural difference oriented, and the distribution is truncated from below, indicating that these MPs rarely engage in 'socio-economic responsibility'

\footnotetext{
${ }^{6}$ For brevity, only excerpts are quoted. Authors' translation.

7Ruedin and Morales (2017) criticize the use of wordfish in the context of parties' immigration position(analyzing manifestos). However, our findings indicate that the wordfish scaling technique is useful in identifying frames of references, rather than anti/pro positions. Speeches demonstrating this point can be found in the supplemental material.

${ }^{8}$ The distribution of KD, the Christian Democratic party, is different because the party emphasizes differences between Christian and Muslim immigrants.
} 
oriented rhetoric. This reflects its emphasis of Swedish nationalism and nativism (Hellstrom et al., 2012) 9

Figure 1: distributions of immigration expressed positions by party

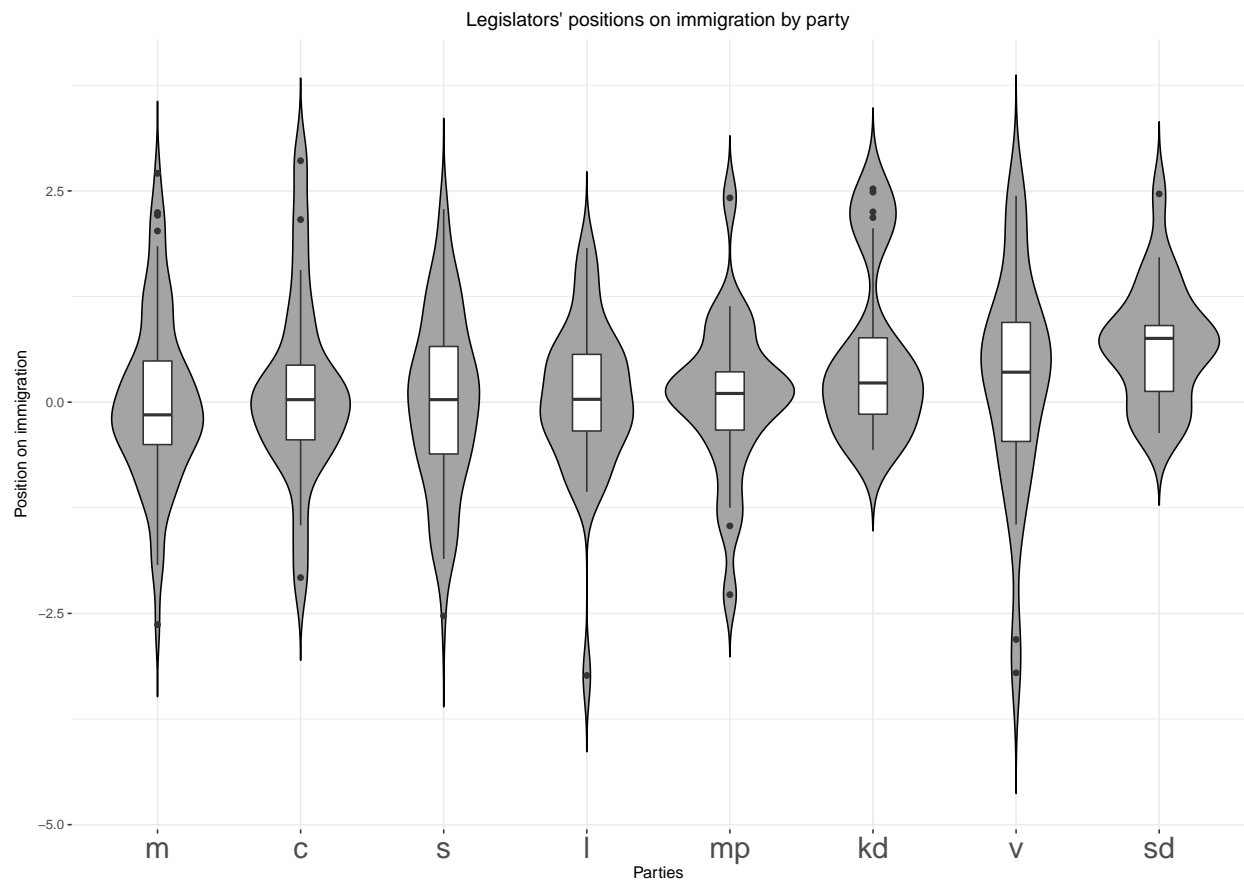

Note: Distributions of parties' expressed positions on immigration. Estimates are aggregated to the MP-median level. Higher values indicate a more cultural difference position. Lower values indicate socio-economic responsibility positions.

We also validate the scale by comparing it to estimates from a structural topic model (STM) (Roberts et al., 2018). The STM offers a framework to estimate the topic of each document (speech). Within this framework, each topic is conceived to be a mixture over words and each word has a probability of belonging to a topic. Below we present the results of a ten topic model, which was selected based on its log-likelihood (Griffiths and Steyvers, 2004) and perplexity (Cao et al., 2009).

Table 2 presents the characteristic words of the topics (labels in bold) ${ }^{10}$ The table reveals that some topics identified by the STM model are closely

\footnotetext{
${ }^{9}$ See supporting material for additional validation.

${ }^{10}$ These words have a high lift parameter (Taddy, 2013), which is the frequency of a word in a given topic divided by its frequency in other topics.
} 
Table 2: characteristic words from a ten topic structural topic model

\begin{tabular}{lllll}
\hline Identity & Reception & Economy & Legality & Education \\
\hline hate crime & unaccompanied youth & woman & rejection & SFI (Swedish for immigrants) \\
racism & refugee children & research & Iraq & integration policy \\
religion & living & budget & court & teaching \\
ethnic & municipality & Kronor & Iraqi & education \\
Muslim & refugee reception & beneficial & migration secretary & national audit office \\
Sweden Democrats & receive & tax & expulsion & migration \\
democratic & place & power & reject & establishment \\
\hline Labour & International & Security & Debates & Children \\
\hline worker & escape & extremism & criticize & child \\
employer & EU & terrorism & head & identity \\
labour force & Europe & scrutiny & listen & citizenship \\
use & fleeing & declare & taken & family \\
abuse & period & organization & interesting & term \\
labour migration & European & against & discussion & wise \\
condition & together & coordination & nothing & kid
\end{tabular}

related to the poles estimated by the wordfish model. Thus, for example, words such as hate crime, racism, and religion appear as having high discriminatory value according to the wordfish model and as being indicative of a topic we label identity. Similarly, words such as unaccompanied youth, municipality and reception are informative according to the wordfish model and are indicative of an STM topic we have labelled reception. Further examination reveals a number of STM topics characterized by words that the wordfish model has also identified as informative.

Given that the STM has identified similar sets of words as the wordfish model, we move to compare the topics. Specifically, we examine the degree to which the wordfish scale estimates correspond to the relevant topic probabilities from the STM algorithm. We should expect strong positive correlations between our scale and the STM identity and security topics, and negative correlations with the reception and economy topics. In Figure 2 we present the relevant correlations, which support our expectations. Six STM topics have substantively significant correlations with the wordfish scale. As expected, identity and security topics are aligned with the wordfish scale. We also note that the legality topic (dealing with the possible deportation of migrants) is highly correlated with the scale. In addition, there are significant negative correlations between the wordfish scale and socio-economic responsibility aspects captured in STM model in topics such as reception, economy and education.

Overall, these findings lend support to the validity of our scale. Even though the wordfish algorithm and the STM are different in terms of the modeling assumptions and outputs (a unidimensional space in the wordfish model and a mixture of topics in the STM), they point to a similar characterization of the immigration discourse in parliament. 
Figure 2: Wordfish and structural topic model correlations

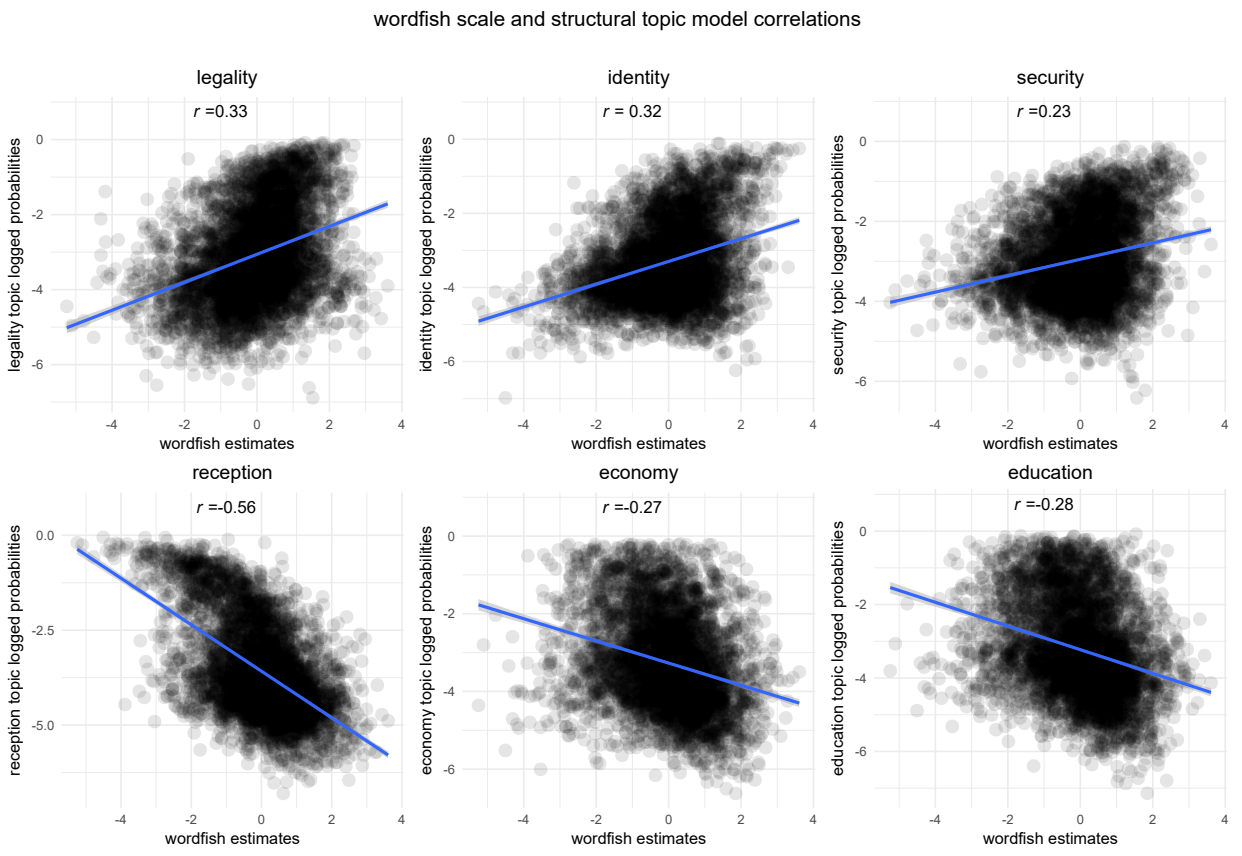

Note: Correlations of the wordfish model $\omega$ parameter with the $\log$ of the $\theta$ (the proportion of each speech that is allocated to a specific topic) STM parameter. The topics presented were selected in a stepwise regression model, regressing the wordfish $\omega$ parameter on speeches' topic probabilities. Correlations of the four other topics with the criterion are below 0.05 .

\section{Findings}

In order to test the relationships between district-level characteristics and MPs' rhetoric, we collected measures of welfare recipients, unemployment, median income, crime (violent crime per 100,000 inhabitants) and percentage of district residents holding no post primary education. The statistical models also include a variable capturing the cost of refugee reception per capita, and the share of the district's residents that are foreign-born 11

We incorporate a number of variables that capture political institutions and MPs' personal characteristics. Based on literature indicating that women have different attitudes towards immigration than men (Blinder, 2015), as

\footnotetext{
${ }^{11}$ Descriptive statistics and data sources can be found in the supporting material.
} 
well as party-specific scholarship reporting that parties with a higher share of women legislators present more social justice policies (Kittilson, 2011), we include a gender variable. Second, we build upon the literature on descriptive representation (Saalfeld and Bischof, 2012), and include an indicator variable for MPs born outside of Sweden. The third individual level variable captures ministerial roles, because ministers' speeches may represent the position of the ministry/government rather than their own opinion or district. We also use binary variables to account for government/opposition status, and a dummy variable indicating whether in a given debate there are severe restrictions in place on speakers (See also Bäck et al. $(2014)$ ). ${ }^{12}$ We also include a binary variable coded one for speeches given after the immigration crisis (November 2015), and zero before. Finally, all models include party indicator variables (estimates not reported).

Since we are interested in the degree to which changes in districts' sociodemographic conditions predict responsiveness, we use yearly changes in levels of welfare recipients, unemployment, median income, and violent crime, as well as in the cost of refugees per capita and the share of district residents that are foreign-born. Due to moderately-high correlations between three of our variables, in some of the models, we also use a variable that captures overall economic change and is based on the scores obtained from a principal component analysis (PCA) on unemployment, welfare recipients, and median income 13

Importantly, we do not claim to have identified the exact causal pathway between district characteristics and speeches. Our approach is to use a number of estimation techniques to ensure that the results are robust to modeling choices. We present results from district fixed effects models, which take into account the potentially biasing effects of unmeasured stable variables. In these models, we cluster the standard errors by district. Second, we use mixed models with district-level intercepts (Gelman and Hill, 2016), in which we estimate district-level random intercepts. These models are useful since if there is not a lot of reliable district-level variation, estimates are

\footnotetext{
${ }^{12}$ The general rule is freedom of speech (Riksdagsordningen 6 kap. 15). However, the speaker (after consulting with parties' leaders) can impose restrictions on the debates. In practice, this rule only affects Current Debates (Aktuell debatt) in which the convention is to limit the number of speakers to one per party, giving the leadership extensive power over who speaks.

${ }^{13}$ The correlations range between 0.54-0.71. We use the principal() function from the psych $\mathrm{R}$ package, employing varimax rotation. See the supporting material for a correlation matrix.
} 
pooled toward the overall district grand mean.

We begin by testing the responsiveness hypothesis, which states that socioeconomic deterioration predicts cultural difference rhetoric. Figure 3 presents the first set of models, including coefficients on five variables of interest. These are the overall change in the district's economy, changes in the share of welfare recipients, median income, unemployment, and crime 14 We estimate both fixed effects and random effects models and incorporate controls for education and institutional factors. The results presented in the figure are highly stable across all models. Beginning with potential confounders, the positive and significant coefficients indicate that in centralized debates the rhetoric is much more oriented towards cultural difference rhetoric. While we do not delve into this result, the magnitude of the relationship is indicative of the importance of legislative selection mechanisms on the type of rhetoric employed in the debate. Conversely, we do not find a relationship between government membership and rhetoric.

Moving to district level variables, the models indicate a significant relationship between the economic variables and rhetoric. Specifically, besides the fixed effects model with $\Delta$ welfare recipients (panel B), in which we cannot reject the null, we find that socio-economic deterioration, captured by any of the relevant variables, is indeed predictive of cultural difference rhetoric. Counter-intuitively, some of the results indicate that a higher proportion of residents holding only primary education is predictive of socio-economic responsibility rhetoric ${ }^{15}$ Finally, the models do not indicate that changes in the cost of refugees and in the share of foreign-born district residents to be predictive of rhetoric.

In Figure 4 we present augmented models, including three individual MP level variables, as well as a crisis-period indicator variable. 16 Again, the results are stable across all model specifications. Male legislators are more difference oriented than females, while speeches of MPs who were born outside of Sweden are significantly more socio-economic responsibility oriented. One model (panel C) points to a marginally significant relationship between the crisis period and rhetoric, but we do not take these to indicate a substantively important result given the null findings in all other model specifications. Importantly, the results in all models provide support for the

\footnotetext{
${ }^{14}$ See Table 1, supporting material.

${ }^{15}$ We note that Arzheimer and Carter (2006) report a similar result, and leave this for future research.

${ }^{16}$ See Table 2, supporting material.
} 
Figure 3: Socio-economic district conditions, institutions and immigration rhetoric

District characteristics and institutions

A

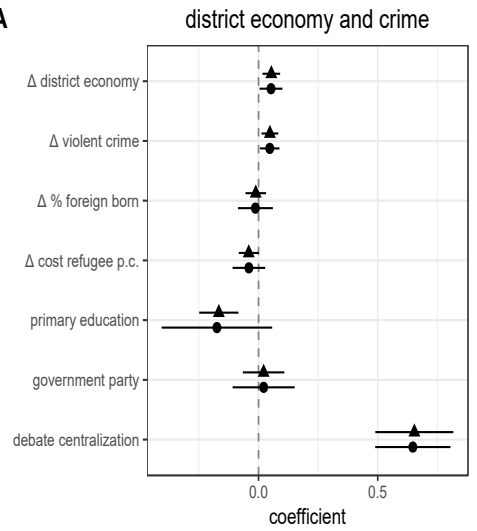

C

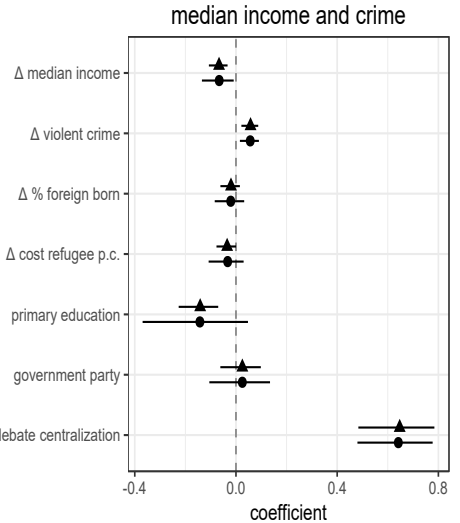

B

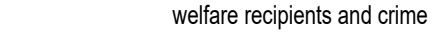

model

fixed effects,

4 random effects

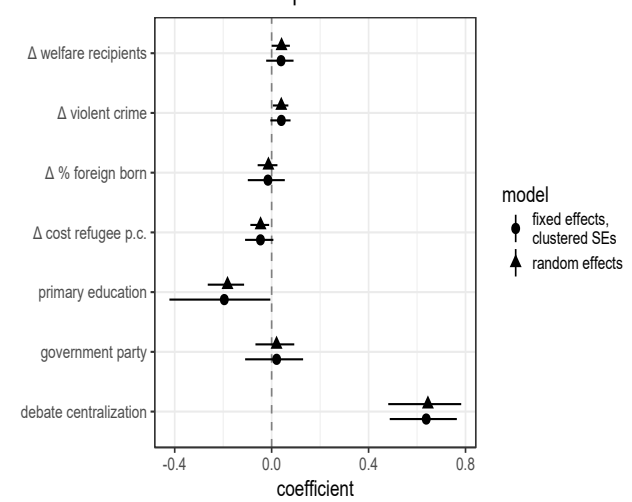

D

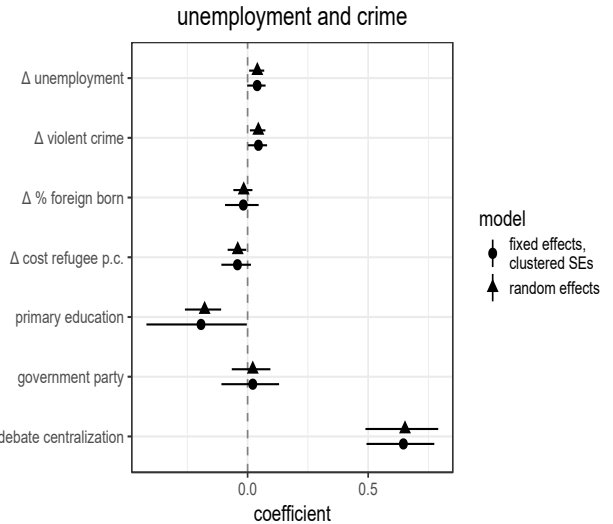

Note: Models predicting the $\beta$ parameter from the scaling model. Positive coefficients indicate that the variable predicts cultural difference discourse. Negative coefficients indicate that the variable predicts socio-economic responsibility discourse. Symbols indicate point estimates and horizontal lines are $90 \%$ confidence intervals. All district level variables have been normalized.

responsiveness hypothesis. Concretely, we find that across all of the specific economic indicators, as well as the composite district economy variable, worse conditions are predictive of more culturally oriented rhetoric. In addition, violent crime is found to be predictive of difference rhetoric. While the magnitude of the effects is not large (one standard deviation in these normalized variables corresponds to 0.04-0.07 change in the dependent 
variable), they are robust and consistent with the theoretical expectation.

Figure 4: district economy, institutions, MP level variables, crisis, and immigration rhetoric

District characteristics, institutions, and MP level variables

A

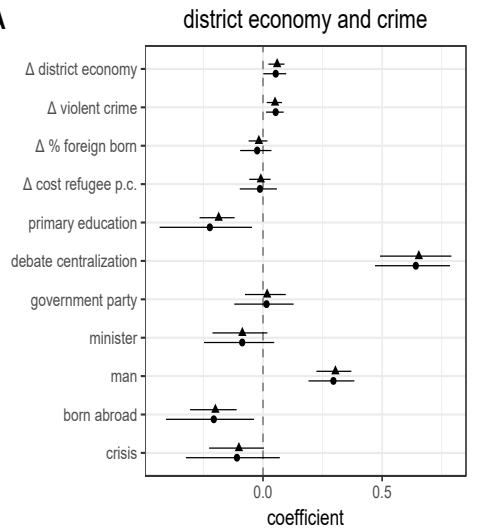

C

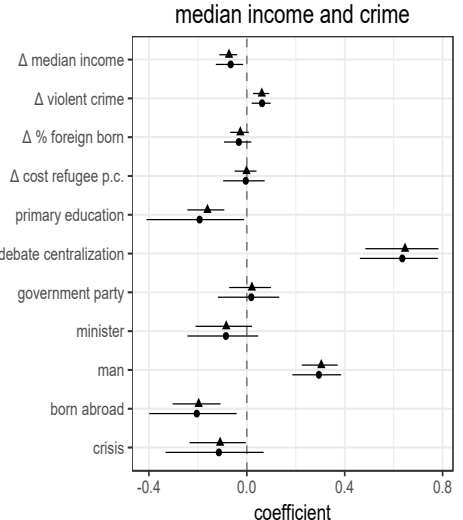

B model fixed effects,
clustered SES $\uparrow$ random effects
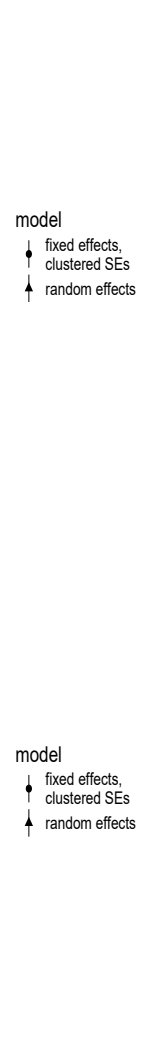

D
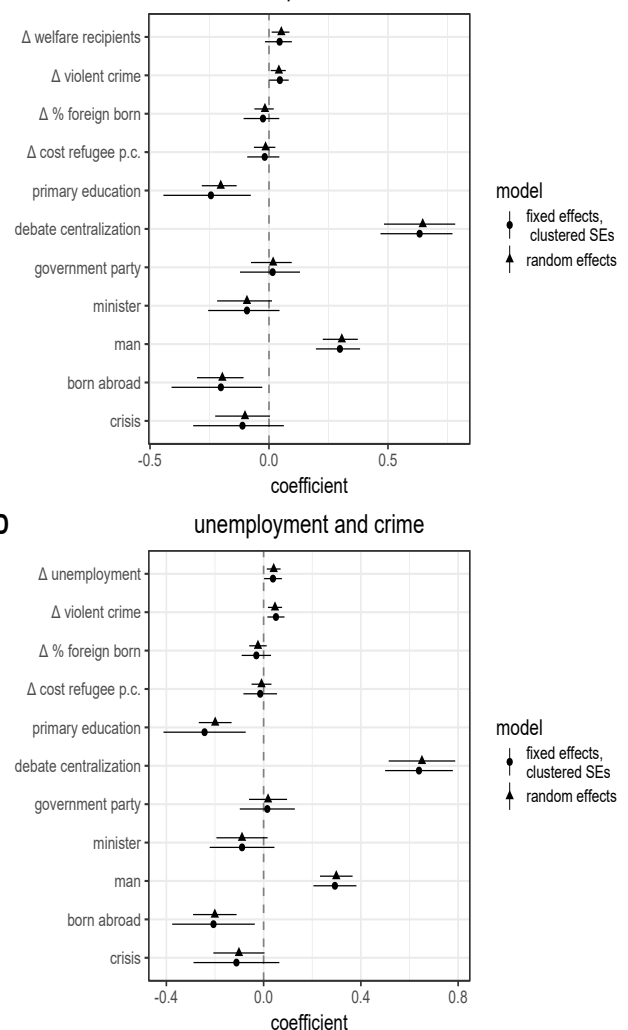

Note: Models predicting the $\beta$ parameter from the scaling model. Positive coefficients indicate that the variable predicts cultural difference discourse. Negative coefficients indicate that the variable predicts socio-economic responsibility discourse. Symbols indicate point estimates and horizontal lines are $90 \%$ confidence intervals. All district level variables have been normalized.

We now examine the opposition hypothesis, stating that responsiveness should be higher for opposition parties. Figure 5 presents the marginal effect of the socio-economic variables, conditional on government status ${ }^{17}$ The results indicate that opposition MPs are more responsive than MPs

\footnotetext{
${ }^{17}$ See Table 3, supporting material.
} 
from government parties, but only when we examine overall economic conditions or change in the share of welfare recipients (Panel A). In the case of the overall index of district economy, the marginal effect for government MPs is indistinguishable from zero, while that of opposition MPs is significant and positive, as hypothesized. The effect is similar in the case of $\Delta$ welfare recipients ${ }^{18}$ Overall, a one standard deviation increase in these standardized variables corresponds a $0.07-0.1$ shift towards the difference pole. However, in the models interacting yearly changes in median income and unemployment with governing status (Panels C and D), we do not find evidence that allows us to reject the null. Overall, these analyses provide limited support for the opposition hypothesis.

Recall that the demography hypothesis stated that responsiveness to socioeconomic demand should be conditional on the ethnic composition of the district. To test this hypothesis, we interact the socio-economic variables with changes in the percentage of foreign-born district residents. We present the marginal effects in Figure 6 and the full models in the supporting material. As can be seen in the figure, and in line with the hypothesis, the relationship between districts' economy and legislators' rhetoric is indeed conditional on the ethnic composition of the district. Specifically, in cases where the share of foreign-born residents diminishes or where the changes are minimal, the relationship between economic hardships and rhetoric is generally insignificant. However, all models indicate that in districts that have experienced larger increases in the share of foreign-born inhabitants, economic hardships have a significant impact on MPs' responsiveness, such that MPs talk in a more cultural difference oriented way.

We now focus on the relationship between ERP district electoral success, and its relationship with responsiveness. However, since the selection of speakers in parliament is not random, identification of this relationship is challenging. Speaker selection is affected by factors such as government agenda control, rules pertaining to debates, and party leadership allocation of speeches across MPs (Proksch and Slapin, 2012). In addition, unobserved factors can affect the probability of speaking, as well as MPs' rhetoric. If these factors are correlated, then traditional estimation techniques such as ordinary least squares and binary dependent variable models, which do not take into account the speech selection process, may yield biased and inconsis-

\footnotetext{
${ }^{18}$ We note that in the case of $\Delta$ district economy, the confidence interval for opposition and government overlap, while they do not in the case of $\Delta$ welfare recipients. We do not present a model interacting crime with government status, but the effect is insignificant in that case as well.
} 
Figure 5: Marginal effect of district-level economy on rhetoric, conditional on government membership

Opposition status and responsiveness

A
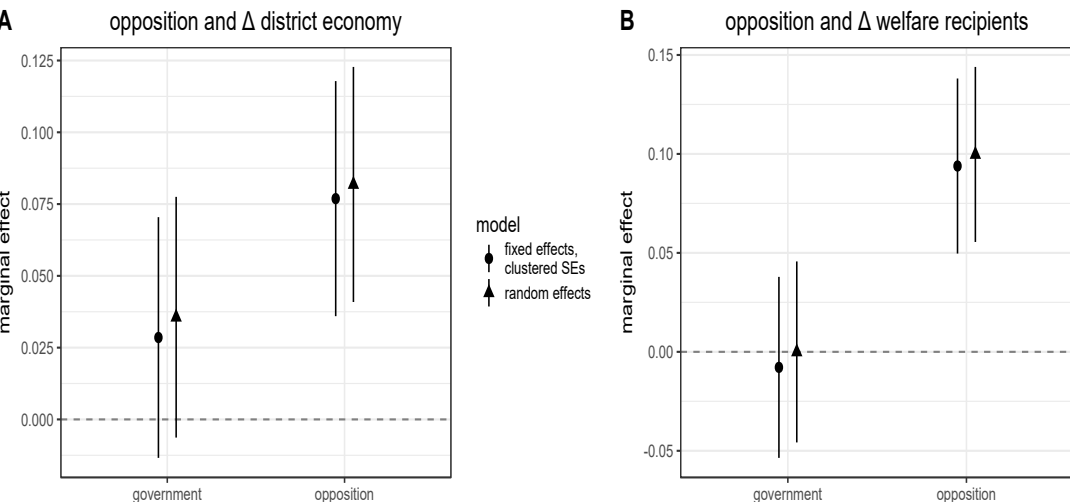

model

fixed effects,

4 random effects

C opposition and $\Delta$ median income
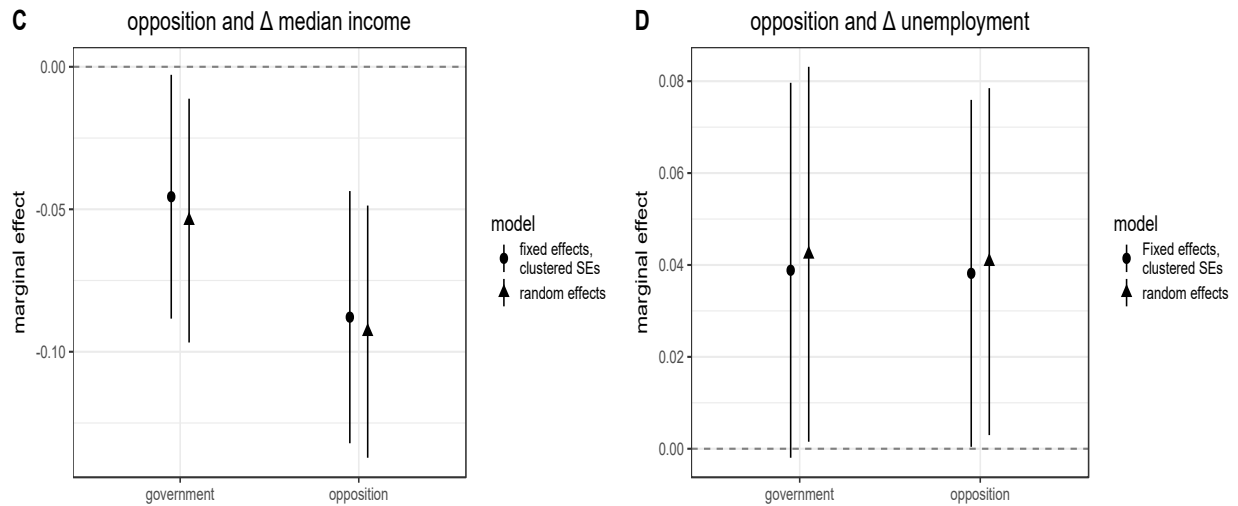

Note: Symbols indicate point estimates. The solid lines are $90 \%$ confidence intervals.

tent results. In effect, we observe a truncated, and possibly unrepresentative sample of positions via speeches, but are interested in learning about both observed and potential positions (Vance and Ritter, 2014). To address these issues, we utilize a sample selection model (Heckman, 1976) ${ }^{19}$ The sample selection model jointly estimates the probability that a given MP will speak in a given debate, as well as her expressed positions.

Our independent variable of interest is the change in the electoral success

\footnotetext{
${ }^{19}$ We use the $\mathrm{R}$ sampleSelection package.
} 
Figure 6: Marginal effect of district-level economy on rhetoric, conditional on demography

District demography and responsiveness
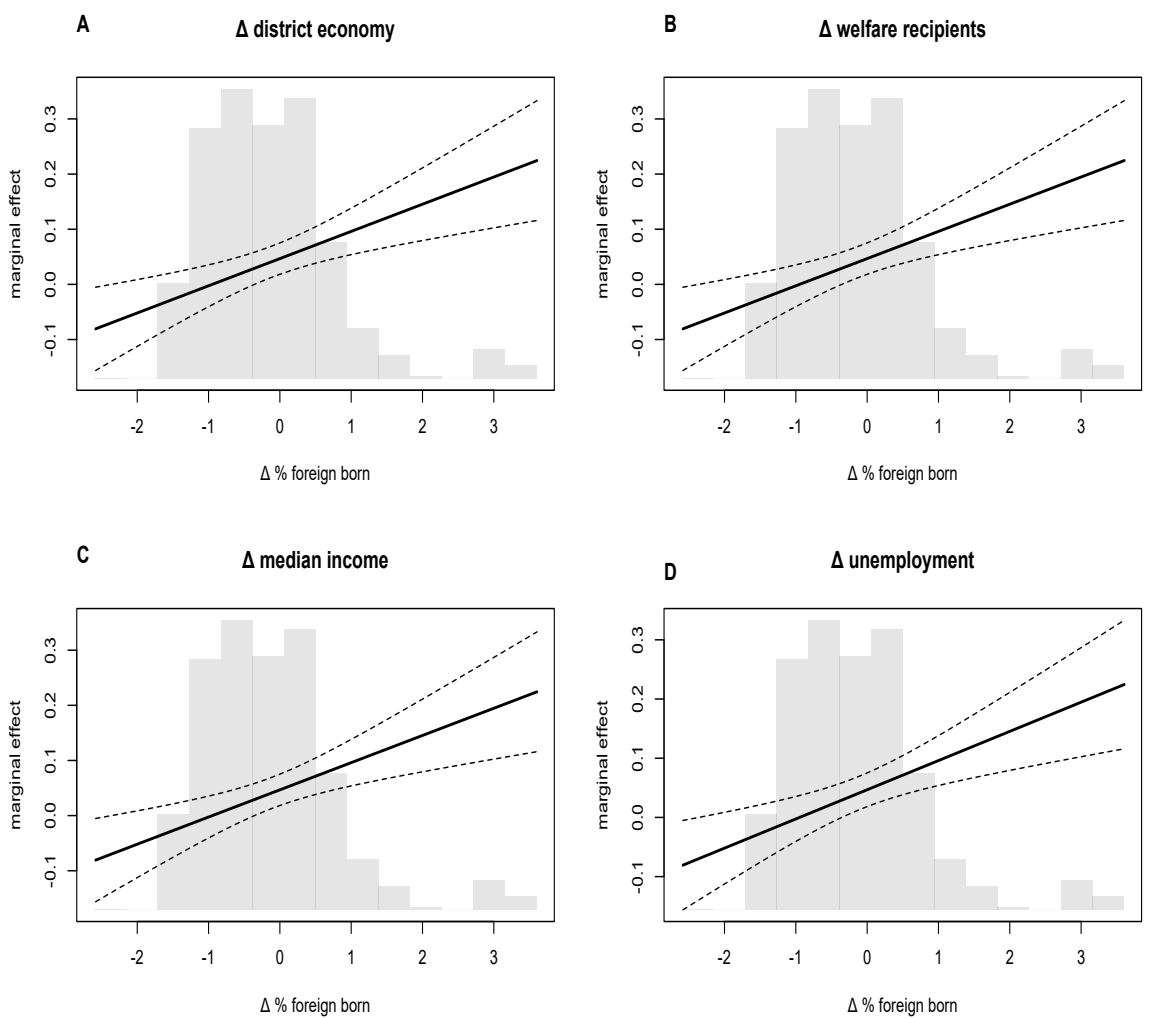

Note: Solid lines are marginal effect of economic change variables. Broken lines are $90 \%$ confidence intervals. Histograms present the density of $\Delta$ foreign born residents. Only the results of the mixed models are presented. Fixed effects models provide similar results.

of the Sweden Democrats in MPs' home districts. To reduce the possibility that spatial correlations are driving the results, we also incorporate the mean change in the election result of the Sweden Democrats in neighboring districts. To isolate the district relationship, we include a variable that measures the national level of change in the share of respondents who have voted for a given party and state they would vote for it in the future. To assuage concerns over unobserved confounders the models include parties 
and district fixed effects. Moreover, following Vance and Ritter (2014) and in order to satisfy the exclusion restriction and ease the identification of the model, we also include two variables that we believe to be predictive of the selection process, but not of the expressed position of MPs, except through the selection process. These are the rank of an MP in the party list, and the number of years she has served in parliament. We limit our sample only to the parliamentary sessions where the Sweden Democrats had won representation, and to MPs who were members of parliament in these sessions 20

Figure 7: Heckman Sample selection model estimates

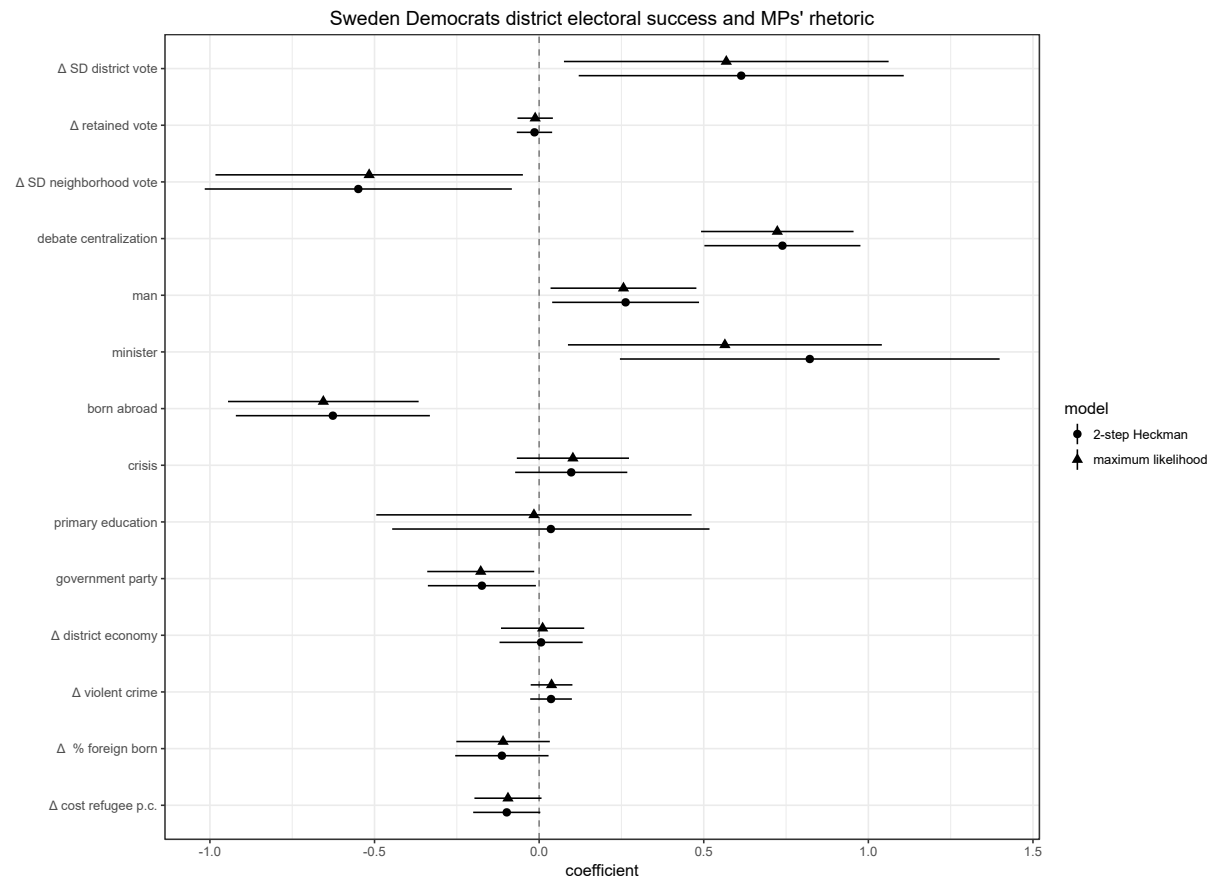

Note: Heckman Sample selection model outcome stage estimates along with $90 \%$ confidence intervals.

We estimate both a 2-step Heckman model (a Heckit model) and a maximum likelihood version of the model. The latter assumes that the error terms of the two stages are jointly normally distributed. If this assumption is true, Wooldridge (2010) notes that maximum likelihood estimation will

\footnotetext{
${ }^{20}$ Including all MPs would bias our results. That is why we do not use selection models to test the other hypotheses.
} 
be more efficient. ${ }^{21}$ Before reviewing the relationship between the ERP's electoral success and MPs positions, we note that both model specifications have identified a significant positive correlation between the selection and the speech stages $(\rho=0.57$ in the Heckit model and 0.42 in the maximum likelihood model), indicating that the use of a sample selection model is justified.

We present the main results of the sample selection model in Figure 7. Most importantly, both models indicate that as the district-level success of the ERP increases, mainstream MPs from the corresponding district shift their position towards the cultural difference pole. Interestingly, the relationship between the country level success of the ERP and MPs' rhetoric is indistinguishable from zero. Finally, due to the shorter period utilized in this model, it is unsurprising to find that the economic change variables relationship with rhetoric is insignificant, but that the MP level variables relationship with rhetoric is similar to that identified in previous models.

\section{Conclusion}

We have argued that district-level socio-economic decline indicates that there is demand for cultural rhetoric on immigration, and have found that MPs are responsive to this demand. We believe this finding to be helpful in understanding the new discourses and political coalitions that are currently being formed in Europe, as issue and identity politics are becoming more salient. We have also found that this type of responsiveness is conditional on demography; as more 'foreigners' inhabit economically deprived districts, MPs feel more inclined to shift towards cultural discourse.

These processes are happening as the Swedish extreme right is gaining ground. The analysis has identified a district-level relationship between its electoral success and a shift toward cultural difference rhetoric. This result is relevant to the debate as to whether ERPs matter. Mudde (2013) has argued that the influence of ERPs on the issue of immigration is limited, and that they are 'catalysts rather than initiators.' While there is no doubting that external circumstances, rather than the Sweden Democrats, have led to the changes in the Swedish policy toward immigrants, this research shows that the party has contributed to changing the mainstream discourse

\footnotetext{
${ }^{21}$ In the supporting material we present the full results, as well as separate OLS and probit models.
} 
of immigration, and to 'mainstreaming' the cultural difference frame. More generally, the analysis provides evidence that an electoral victory is not a necessary condition for a important rhetorical changes. Rather, the mere threat of the extreme-right can have a strong impact on the political discourse in European Democracies. 


\section{References}

Abou-Chadi, T. (2016). Niche party success and mainstream party policy shifts how green and radical right parties differ in their impact. British Journal of Political Science, 46(2):417-436.

Adams, J., Clark, M., Ezrow, L., and Glasgow, G. (2004). Understanding change and stability in party ideologies: Do parties respond to public opinion or to past election results? British Journal of Political Science, 83(1):589-610.

Adams, J., Haupt, A. B., and Stoll, H. (2008). What moves parties? Comparative Political Studies, 42(5):611639.

Adams, J. and Somer-Topcu, Z. (2009). Policy adjustment by parties in response to rival parties policy shifts: Spatial theory and the dynamics of party competition in twenty-five post-war democracies. British Journal of Political Science, 39(4):825-846.

Ansolabehere, S., Snyder, J. M., and Stewart, C. (2001). Candidate positioning in u.s. house elections. American Journal of Political Science, 45(1):136-159.

Arzheimer, K. and Carter, E. (2006). Political opportunity structures and right-wing extremist party success. European Journal of Political Research, 45(3):419-443.

Bäck, H., Debus, M., and Müller, J. (2014). Who takes the parliamentary floor? the role of gender in speech-making in the swedish riksdag. Political Research Quarterly, 67(3):504-518.

Bale, T. (2003). Cinderella and her ugly sisters: The mainstream and extreme right in europe's bipolarising party systems. West European Politics, 26(3):67-90.

Baumann, M., Debus, M., and Müller, J. (2015). Personal characteristics of mps and legislative behavior in moral policymaking. Legislative Studies Quarterly, 40(2):179-209.

Benoit, K. and Laver, M. (2007). Estimating party policy positions: Comparing expert surveys and hand-coded content analysis. Electoral Studies, 26(1):90107.

Betz, H.-G. (1993). The new politics of rsentment: Radical right-wing populist parties in western europe. Comparative Politics, 25(4):413-427. 
Blinder, S. (2015). Imagined immigration: The impact of different meanings of 'immigrants' in public opinion and policy debates in britain. Political Studies, 63(4):80-100.

Borghetto, E. and Russo, F. (2018). From agenda setters to agenda takers? the determinants of party issue attention in times of crisis. Party Politics, $24(1): 65-77$.

Bornschier, S. (2010a). Cleavage Politics and the Populist Right. Temple University Press.

Bornschier, S. (2010b). The new cultural divide and the two-dimensional political space in western europe. West European Politics, 33(3):419-444.

Burns, P. and Gimpel, J. (2000). Economic insecurity, prejudicial stereotypes, and public opinion on immigration policy. Comparative Political Studies, 115(2):201-225.

Burscher, B., van Spanje, J., and de Vreese, C. H. (2015). Owning the issues of crime and immigration: The relation between immigration and crime news and anti-immigrant voting in 11 countries. Electoral Studies, 38:59-69.

Butler, D. M., Naurin, E., and Ohberg, P. (2016). Party representatives adaptation to election results dyadic responsiveness revisited. Comparative Political studies.

Cao, J., Xia, T., Li, J., Zhang, Y., and Tang, S. (2009). A density-based method for adaptive lda model selection. Neurocomputing, 72(7):17751781 .

Carey, J. and Shugart, M. (1995). Incentives to cultivate a personal vote: A rank ordering of electoral formulas. Electoral Studies, 14(4):417-39.

Carmines, E. G. and Stimson, J. A. (1990). Issue evolution: race and the transformation of American politics. Princeton University Press.

Clarke, H. D., Goodwin, M., and Whiteley, P. (2017). Why britain voted for brexit: An individual-level analysis of the 2016 referendum vote. Parliamentary Affairs, pages 1-26.

Dahlstrom, C. and Sundell, A. (2012). A losing gamble. how mainstream parties facilitate anti-immigrant party success. Electoral Studies, 31(2):353363. 
Dalton, R. J. (2015). Party representation across multiple issue dimensions. Party Politics, 23(6):609622.

Dalton, R. J. and McAllister, I. (2014). Random walk or planned excursion?: Continuity and change in the left-right positions of political parties. Comparative Political Studies, 48(6):759-787.

de Vries, C. E., Hakhverdian, A., and Lancee, B. (2013). The dynamics of voters' left/right identification: The role of economic and cultural attitudes. Political Science Research and Methods, 1(2):223-238.

Dinas, E. and van Spanje, J. (2011). Crime story: The role of crime and immigration in the anti-immigration vote. Electoral Studies, 30(4):658671.

Enelow, J. N. and Hinich, M. J. (1984). The spatial theory of voting: An introduction. Cambridge University Press, Cambridge, UK.

Fennema, M. (2005). Poulist parties of the right. In Rydgren, J., editor, Movements fo Exclusion: Radical Right-Wing Populism in the Western World. Nova Science, New York.

Fernandes, J. M., Leston-Bandeira, C., and Schwemmer, C. (2017). Election proximity and representation focus in party-constrained environments. Party Politics, page 1354068817689955.

Gelman, A. and Hill, J. (2016). Data analysis using regression and multilevel / hierarchical models. University Press.

Gilljam, M. and Brothen, M. (1994). Mellanvalsdemokrati. In Hanna, B. and Gilljam, M., editors, Demokratins mekanismer. Liber, Malmo.

Golder, M. (2003). Explaining variation in the success of extreme right parties in western europe. Comparative Political Studies, 36(4):432-466.

Green-Pedersen, C. (2007). The growing importance of issue competition: The changing nature of party competition in western europe. Party Politucs, 55(5):607-628.

Green-Pedersen, C. and Krogstrup, J. (2008). Immigration as a political issue in denmark and sweden. European Journal of Political Research, 47(5):610-634.

Greene, Z. (2016). How experience in government and economic conditions influence the scope of parties' policy messages. Party Politics, 22(6):809822 . 
Griffiths, T. L. and Steyvers, M. (2004). Finding scientific topics. Proceedings of the National Academy of Sciences, 101(suppl 1):5228.

Hagelund, A. (2003). A matter of decency? the progress party in norwegian immigration politics. Journal of Ethnic and Migration Studies, 29(1):4765 .

Haidt, J. (2016). When and why nationalism beats globalism. Policy: A Journal of Public Policy and Ideas, 32(3):46-53.

Hanretty, C., Lauderdale, B. E., and Vivyan, N. (2016). Dyadic representation in a westminster system. Legislative Studies Quarterly, 42(2):235-267.

Heck, S. V. (2016). Appealing broadly or narrowing down? the impact of government experience and party organization on the scope of parties issue agendas. Party Politics, page 135406881665737.

Heckman, J. J. (1976). The common structure of statistical models of truncation, sample selection and limited dependent variables and a simple estimator for such models. Annals of Economic and Social Measurement, $5(4): 475-492$.

Hellstrom, A., Nilsson, T., and Stoltz, P. (2012). Nationalism vs. nationalism: The challenge of the sweden democrats in the swedish public debate. Government and Opposition, 47(2):186-205.

Herzog, A. and Benoit, K. (2015). The most unkindest cuts: Speaker selection and expressed government dissent during economic crisis. Journal of Politics, 77(4):1158-1174.

Hobolt, S. B. and Tilley, J. (2016). Fleeing the centre: the rise of challenger parties in the aftermath of the euro crisis. West European Politics, 39(5):971-991.

Hobolt, S. B. and Vries, C. E. d. (2015). Issue entrepreneurship and multiparty competition. Comparative Political Studies, 48(9):1159-1185.

Hoeglinger, D. (2016). Politicizing European integration: struggling with the awakening giant. Palgrave Macmillan in the US is a division of St Martins Press LLC.

Hooghe, L. and Marks, G. (2009). A postfunctionalist theory of european integration: From permissive consensus to constraining dissensus. British Journal of Political Science, 39(1):1-23. 
Hooghe, L. and Marks, G. (2018). Cleavage theory meets europe's crises: Lipset, rokkan, and the transnational cleavage. Journal of European Public Policy, 25(1):109-135.

Hooghe, L., Marks, G., and Wilson, C. J. (2002). Does left/right structure party positions on european integration? Comparative Political Studies, 35(8):965-989.

Kitschelt, H. P. (1986). Political opportunity structures and political protest: Anti-nuclear movements in four democracies. British Journal of Political Science, 16(1):57-85.

Kittilson, M.-C. (2011). Women, parties and platforms in post-industrial democracies. Party Politics, 17(1):66-92.

Klüver, H. and Sagarzazu, I. (2015). Setting the agenda or responding to voters? political parties, voters and issue attention. West European Politics, 39(2):380-398.

Klüver, H. and Spoon, J.-J. (2016). Who responds? voters, parties and issue attention. British Journal of Political Science, 46(3):633654.

König, T., Marbach, M., and Osnabrügge, M. (2017). Left/right or u? estimating the dimensionality of national party competition in europe. The Journal of Politics, 79(3):1101-1105.

Kriesi, H., Grande, E., Lachat, R., Dolezal, M., Bornschier, S., and Frey, T. (2008). West European Politics in the Age of Globalization. Cambridge: Cambridge University Press, Cambridge, UK.

Kriesi, H., Grande, E., Lachat, R., Dolzeal, M., Bornschier, S., and Frey, T. (2006). Globalization and the transformation of the national political space: Six european countries compared. European Journal of Political Research, 45(6):921-956.

Krimmel, K., Lax, J. R., and Phillips, J. H. (2016). Gay rights in congress. Public Opinion Quarterly, 80(4):888913.

Lauderdale, B. E. and Herzog, A. (2016). Measuring political positions from legislative speech. Political Analysis, 24(3):374-394.

Lucas, C., Nielsen, R. A., Roberts, M. E., Stewart, B. M., Storer, A., and Tingley, D. (2015). Computer-assisted text analysis for comparative politics. Political Analysis, 23(2):254-277. 
Maltzman, F. and Sigelman, L. (1996). The politics of talk: Unconstrained floor time in the u.s. house of representatives. The Journal of Politics, $58(3): 819-830$.

Martin, L. W. and Vanberg, G. (2007). Coalition government and political communication. Political Research Quarterly, 61(3):502-516.

Mayhew, D. (1974). Congress: The Electoral Connection. Yale University Press, New, Haven, CT.

Meguid, B. M. (2005). The role of mainstream party strategy in niche party success. American Journal of Political Science, 99(3):347-359.

Minkenberg, M. (2001). The radical right in public office: Agenda-setting and policy effects. West European Politics, 24(4):1-21.

Mudde, C. (2007). Populist Radical Right Parties in Europe. Cambridge University Press, Cambridge.

Mudde, C. (2013). Three decades of populist radical right parties in western europe: So what? European Journal of Politia Research, 52(1):1-19.

Norris, P. (2005). Radical right: voters and parties in the electoral market. Cambridge University Press.

Odmalm, P. (2011). Political parties and the immigration issue: Issue ownership in swedish parliamentary elections 19912010. West European Politics, 34(5):1070-1091.

Oskarson, M. and Demker, M. (2015). Room for realignment: The workingclass sympathy for sweden democrats. Government and Opposition, $50(4): 629-651$.

Proksch, S.-O. and Slapin, J. B. (2009). How to avoid pitfalls in statistical analysis of political texts: The case of germany. German Politics, 18(3):323-344.

Proksch, S.-O. and Slapin, J. B. (2010). Position taking in european parliament speeches. British Journal of Political Science, 40(3):587-611.

Proksch, S.-O. and Slapin, J. B. (2012). Institutional foundations of legislative speech. American Journal of Political Science, 56(3):530-537.

Prosser, C. (2016). Dimensionality, ideology and party positions towards european integration. West European Politics, 39(4):731-754. 
Riker, W. H. (1986). The art of political manipulation. Yale University Press.

Roberts, M. E., Stewart, B. M., and Tingley, D. (2018). stm: R Package for Structural Topic Models. R package version 1.3.3.

Ruedin, D. and Morales, L. (2017). Estimating party positions on immigration: Assessing the reliability and validity of different methods. Party Politics, page 1354068817713122.

Rydgren, J. (2008). Immigration sceptics, xenophobes or racists?: Radical right-wing voting in six west european countries. European Journal of Political Research, 47(6):737-765.

Rydgren, J. and Ruth, P. (2011). Voting for the radical right in swedish municipalities: Social marginality and ethnic competition? Scandinavian Political Studies, 34(3):202-225.

Rydgren, J. and Ruth, P. (2013). Contextual explanations of radical rightwing support in sweden: socioeconomic marginalization, group threat, and the halo effect. Ethnic and Racial Studies, 36(4):711-728.

Saalfeld, T. and Bischof, D. (2012). Minority-ethnic mps and the substantive representation of minority interests in the house of commons, 20052011. Parliamntary Affairs, 66:305-328.

Schumacher, G. and Kersbergen, K. v. (2014). Do mainstream parties adapt to the welfare chauvinism of populist parties? Party Politics, 22(3):300312 .

Slapin, J. B. and Proksch, S.-O. (2008). A scaling model for estimating timeseries party positions from texts. American Journal of Political Science, $52(3): 705-722$.

Somer-Topcu, Z. (2009). Timely decision: The effect of past national elections on party policy change. Journal of Politics, 71(1):238-248.

Spanje, J. v. (2010). Contagious parties: Anti-immigration parties and their impact on other parties' immigration stances in contemporary western europe. Party Politics, 16(5):563-586.

Spoon, J.-J., Hobolt, S. B., and Vries, C. E. D. (2013). Going green: Explaining issue competition on the environment. European Journal of Political Research, 53(2):363380. 
Taddy, M. (2013). Multinomial inverse regression for text analysis. Journal of the American Statistical Association, 108(503):755-770.

Tzelgov, E. (2012). Damned if you do and damned if you don't: Rhetorical heresthetic in the israeli knesset. Party Politics, 20(6):964-982.

Van Der Brug, W. and Van Spanje, J. (2009). Immigration, europe and the 'new' cultural dimension. European Journal of Political Research, 48(3):309-334.

Van-Heerden, S., De-Lange, S. L., Der-Brug, W., and Fennema, M. (2014). The immigration and integration debate in the netherlands: Discursive and programmatic reactions to the rise of anti-immigration parties. Journal Journal of Ethnic and Migration Studies, 40(1):119-136.

van Kersbergen, K. and Krouwel, A. (2008). A double-edged sword! the dutch centre-right and the foreigners issue. Journal of European Public Policy, 15(3):398-414.

Van-Spanje, J. (2010). Contagious parties: Anti-immigration parties and their impact on other parties immigration stances in contemporary western europe. Party Politics, 16(5):563-586.

Vance, C. and Ritter, N. (2014). Is peace a missing value or a zero?: On selection models in political science. Journal of Peace Research, 51(4):528540 .

Widfeldt, A. (2015). Tensions beneath the surface the swedish mainstream parties and the immigration issue. Acta Politica, 50(4):399-416.

Williams, C. and Spoon, J.-J. (2015). Differentiated party response: The effect of euroskeptic public opinion on party positions. European Union Politics, 16(2):176-193.

Wooldridge, J. M. (2010). Econometric analysis of cross section and panel data. MIT Press. 